\title{
Effect of Sulfate Supply Level on Sulfate Assimilation in Different Oilseed Rape Cultivars
}

\author{
Qian Zhang, Sang-Hyun Park, Sowbiya Muneer and Tae-Hwan Kim
}

\section{유채 품종별 황 공급수준이 황산염 동화에 미치는 영향}

\author{
장 천 · 박상현 · 소비야 무니르·김태환
}

\begin{abstract}
요 약
유채 품종에서 황 공급수준이 황산염 흡수 및 동화에 미치는 영향을 구명하고자 어린 잎과 성엽 조직에서 ATP sulfurylase (ATPs), $\mathrm{SO}_{4}{ }^{2-}$ 흡수, 글루타치온 함량을 분석하였다. 본 실험에서 10 가지 유 채 품종들 (Mosa, Capitol, Saturnin, Akela, Pollen, Mokpo, Youngsan, Tamra Colosse 그리고 Naehan)은 황 공급수준에 따라 몇 가지 황산염 흡수와 동화 능력이 다르게 나타났다. 황 결핍 조건에서 모든 품 종의 ATP sulfurylase (ATPs) 활력은 늙은 잎에 비해 어린 잎에서 높게 나타났으며, 글루타치온 함량은 황 공급수준이 감소함에 따라 어린 잎에서 많이 증가하였다. 이러한 결과들은 유채 품종별 황 결핍 조건에서 황을 이용하는 능력이 다르다는 것을 잘 보여주었다.
\end{abstract}

(Key words : Brassica napus, ATP sulfurylase, Glutathione, Sulfate deficiency, Sulfate metabolism)

\section{I . INTRODUCTION}

Sulfur(S) is an essential element for plant growth. In higher plants, $\mathrm{S}$ enters the plant mainly via the roots from soil solution as the form of $\mathrm{SO}_{4}{ }^{2-}$. Then it is transported through the xylem to leaves, delivered to cells and stored in the vacuole or transferred into chloroplasts, where it is activated by adenylation to adenosine-5'-phopsphosulfate, catalyzed by ATP sulfurylase, the first enzyme of sulfate assimilation (Herschbach and Rennenberg, 1991). As Clarkson et al. (1983) and Bell et al. (1995) suggested that $\mathrm{SO}_{4}{ }^{2-}$ is only released from vacuoles of mesophyll cells when plant exposed to a prolonged $\mathrm{S}$ stress and this process is too slow to support new growth. Thus, the first symptoms are exhibited in developing leaves when plant grown in minus $\mathrm{S}$ nutrient (Blake-Kalff et al., 1998).

In plant, the proportion of $\mathrm{S}$ only ranges from 0.1 to $1.5 \%$ of dry weight (Ahmad et al., 2005). However, it plays a critical role in catalytic or electrochemical function in cells (Saito, 2004). For instance, $\mathrm{S}$ is essential for amino acids (Cys and Met), oligopeptides (glutathione), as well as

전남대학교 (Chonnam National University, Gwangju 500-757, Korea)

* BK21 Research Team for the Control of Animal Hazards using Biotechnology, College of Agriculture \& Life Science, Chonnam National University, Gwangju 500-757, Korea

Corresponding author:Tae-Hwan Kim, Department of Animal Science, Institute of Agriculture Science and Technology, College of Agriculture \& Life Science, Chonnam Chonnam National University, Gwangju 500-757, Korea. Tel: +82-62-530-2126, Fax: +82-62-530-2129, E-mail: grassl@chonnam.ac.kr 
vitamins and some cofactors (Leustek, 2002). Glutathione (GSH) is the most abundant nonprotein thiol in many organisms (Noctor et al., 2002). And it has been suggested that GSH is the main form of reduced sulfur transported from shoot to root (Herschbach et al., 2000). In addition, the investigation using 'split-root' method was evident that GSH acted as a negative signal for sulfate uptake, and it is also important for defense against various stressed conditions, including oxidative stress caused by active oxygen species, xenobiotics or some heavy metals (Lappartient et al., 1999; Ruiz and Blumwald, 2002).

Rape species (Brassica napus L.) are particularly sensitive to $\mathrm{S}$ deficiency as it has a high demand for S (Holmes, 1980). Zhao et al. (1997) demonstrated that a large quantity of Scontaining amino acids is required for production of seeds. However, with the decrease of sulfur from industrialized areas, S deficiency in agricultural soils has been occurred in the past few years (Scherer, 2001). In some European countries $\mathrm{S}$ has become one of the most limiting nutrients in agricultural production (Eriksen et al., 2004). In North America, S deficiency was also observed in some agricultural species (Legge and Krupa, 2002). On the other hand, the application of mineral fertilizer is not always the ideal solution when considering the influence of agronomic, environmental and economic factors (Aulakh, 2003). Therefore, the identification of S-efficient rape genotype is necessary. The demand of $\mathrm{S}$ generally varies with different rape cultivars, which reflect the capability of $\mathrm{S}$ uptake and their assimilation at the whole plant level. However, to our knowledge, relatively little information has been available on the sulfur utilization among various oilseed rape cultivars, especially when sulfur nutrition is limited.

In present study, we hypothesize that under S-deficiency conditions the oilseed rape cultivars respond differently to sulfate supply level for the assimilation of sulfate taken up. To test this hypothesis, the activity of ATPs and GSH content were analyzed in ten different cultivars of rape plants grown under S-sufficient or S-limited conditions.

\section{П. MATERIALS AND METHODS}

\section{Plant culture and treatment}

Seeds of rape (Brassica napus L.) were surfacesterilized by a consecutive washing with Tween 20 and 80\% ethanol (Kim et al., 1991). And then they were germinated in bed soil. When seedlings were grown to the 3-leaf stage, they were transferred to $2.3 \mathrm{~L}$ pots filled with $2 \mathrm{~L}$ of complete nutrient solution containing $0.5 \mathrm{mM}$ $\mathrm{KH}_{2} \mathrm{PO}_{4}, 0.5 \mathrm{mM} \mathrm{K} \mathrm{HPO}_{4}, 0.5 \mathrm{mM} \mathrm{MgSO} 4,1.0$ $\mathrm{mM} \mathrm{NH} \mathrm{NO}_{3}, 1.5 \mathrm{mM} \mathrm{K}_{2} \mathrm{SO}_{4}, 1.5 \mathrm{mM} \mathrm{CaCl}_{2}$. $2 \mathrm{H}_{2} \mathrm{O}, 0.2 \mathrm{mM} \mathrm{Fe} \cdot \mathrm{Na} \cdot$ EDTA and mixed microelements. The nutrient solution was changed every 5 days to minimize $\mathrm{pH}$ shift and nutrient depletion. These plants were cultivated in a greenhouse with a day/night mean temperature of $27 / 20^{\circ} \mathrm{C}$, and a relative humidity of $65 / 80 \%$. In addition to natural light, supplemental light was given by metal halide lamps which generated approximately $400 \mu \mathrm{M}$ photons $\mathrm{m}^{-2} \mathrm{~s}^{-1}$ at the canopy height for $16 \mathrm{~h}$ per day.

Eight-week-old plants with good uniformity were selected for the treatment of different $\mathrm{SO}_{4}{ }^{2-}$ supply levels. Two levels $(0.2 \mathrm{mM}$ and $2.0 \mathrm{mM})$ of $\mathrm{SO}_{4}{ }^{2-}$ were supplied by modifying the concentration of $\mathrm{SO}_{4}{ }^{2-}$ source in nutrient solution 
using $\mathrm{MgCl}_{2}$ to substitute for $\mathrm{MgSO}_{4}$ to bring S-deficient conditions. Plants were harvested after 3-day treatment. Each plant was separated into old leaves, middle leaves, young leaves and roots. Leaves were separated by the order of ontogenic appearance, which was designated as leaf number (i.e. giving leaf No. 1 for the oldest leaf). In this study, the leaf ranks numbered 4 and 5 were considered as mature leaves, and up to 8 as young leaves. The leaf samples were immediately frozen in liquid $\mathrm{N}_{2}$ and stored in deep freezer for further analysis.

\section{Sulfate uptake}

Sulfate uptake was estimated by depletion method, which determined the reduced concentration of specific ion in the complete nutrient solution. Nutrient concentration in the solution was measured at a series of different time intervals. The difference between initial and final amounts of nutrient was attributed to root uptake. In present study, sampling of nutrient solution was carried out when each treatment was applied, and consecutively every day. Nutrient solution was filtered through a $25 \mu \mathrm{M}$ syringe filter. The concentration of sulfate in sample solution was determined by ion exchange chromatography (Dionex, DX-120; USA), using an isocratic $\mathrm{Na}_{2} \mathrm{CO}_{3} / \mathrm{NaHCO}_{3}$ eluent $(1.8 \mathrm{mM} /$ $1.7 \mathrm{mM}$ ), and flow rate $2.3 \mathrm{~mL} \mathrm{~min}^{-1}$. A sample volume of $25 \mu \mathrm{L}$ was injected via an auto injector (AS40 Automated Sampler) into an IonPac AS4A-SC guard column and IonPac AS4A-SC analytical columns, coupled to an ASRS ULTRA II (4 mm) Anion Self- Regenerating.

\section{ATP sulfurylase}

About $0.2 \mathrm{~g}$ fresh leaves were rapidly ground at $4^{\circ} \mathrm{C}$ in a buffer consisting of $10 \mathrm{mM}$ $\mathrm{Na}_{2}$ EDTA, $20 \mathrm{mM}$ Tris- $\mathrm{HCl}(\mathrm{pH}$ 8.0), $2 \mathrm{mM}$ DTT and $0.01 \%$ insoluble PVP, using a $1: 4$ $(w / v)$ tissue to buffer ratio. The homogenate was centrifuged at $13,000 \mathrm{rpm}$ for $10 \mathrm{~min}$ at $4{ }^{\circ} \mathrm{C}$. The resulting supernatant was used for ATP sulfurylase assays. ATP sulfurylase activity was measured using molybdate-dependent formation of pyrophosphate, as described by Lappartient and Touraine (1996). The reaction was initiated by adding $200 \mu \mathrm{L}$ of crude extract to $1 \mathrm{~mL}$ of the reaction mixture, which contained $7 \mathrm{mM}$ $\mathrm{MgCl}_{2}, 5 \mathrm{mM} \mathrm{Na} \mathrm{MoO}_{4}, 2 \mathrm{mM} \mathrm{Na} \mathrm{Na}_{2} \mathrm{ATP}$, and lunit of sulfate-free inorganic pyrophosphatase (Sigma, USA) $20 \mathrm{mM}$ Tris-HCl buffer ( $\mathrm{pH}$ 8.0). Another aliquot from the same extract was added to the same reaction mixture without $\mathrm{Na}_{2} \mathrm{MoO}_{4}$. After incubation at $37^{\circ} \mathrm{C}$ for $15 \mathrm{~min}$, $1 \mathrm{~mL}$ of $10 \%$ TCA (TCA/acetone, w/v) was added to stop reaction and was centrifuged (13,000 rpm for $15 \mathrm{~min}), 1 \mathrm{~mL}$ supernatant was mixed with $1 \mathrm{~mL}$ color reagent solution $(2.5 \%$ ammonium molybdate and $0.125 \%$ ammonium metavanadate), and then incubation at $35^{\circ} \mathrm{C}$ for $30 \mathrm{~min}$ was followed. The absorbance was immediately measured at $420 \mathrm{~nm}$. ATP sulfurylase activity was calculated from a standard curve obtained from known concentrations of $\mathrm{PO}_{4}{ }^{3-}$. One unit of ATP sulfurylase activity was defined as the amount of enzyme that liberated $1 \mathrm{nmol}$ of $\mathrm{PO}_{4}{ }^{3-}$ per min.

\section{Glutathione determination}

For the measurement of GSH concentration in leaves, $0.2 \mathrm{~g}$ fresh tissue was extracted by 1.0 $\mathrm{mL} \quad 5 \% \quad 5$-sulfosalicylic acid. $900 \mu \mathrm{L}$ reaction mixtures contained $143 \mathrm{mM} \mathrm{Na}-\mathrm{PO}_{4}$ buffer $(\mathrm{pH}$ 
7.5), $6.3 \mathrm{mM} \mathrm{Na}{ }_{2}$ EDTA, $0.67 \mathrm{mM} \mathrm{5,} \mathrm{5-Dithiobis-}$ 2-nitrobenzoic acid(DTNB) and $0.22 \mathrm{mM} \mathrm{NADP}{ }^{+}$. Reaction of $100 \mu \mathrm{L}$ extraction was initiated by adding $10 \mu \mathrm{L}$ glutathione reductase. Changes in absorbance at $412 \mathrm{~nm}$ during $2 \mathrm{~min}$ were measured. Standard curve which was made with several different concentrations of GSH was used.

\section{Statistical Analysis}

A completely-randomized design was used with three replicates. An individual pot containing three plants represented a replicate. Duncan's multiple range tests were used to compare the means of separate replicates. Unless otherwise stated, statistical significance was postulated for $\mathrm{p}=0.05$.

\section{RESULTS}

\section{ATP sulfurylase activity in response to S-deficiency}

Under complete $\mathrm{SO}_{4}{ }^{2-}(2.0 \mathrm{mM})$ conditions, ATP sulfurylase activity was variable in young leaves, representing a range from 81.9 (Tamra) to $123.5 \mathrm{U} \cdot \mathrm{g}^{-1}$ fresh weight (FW) (Naehan) (Table 1), which was higher than that of old leaves except in pollen. In contrast, the activity dramatically decreased by 3 days S-deficient $(0.2$ $\mathrm{mM} \mathrm{SO}{ }_{4}{ }^{2-}$ ) treatment both in young and old leaves, but the decreasing ratio was higher in old ones. Under S-deficient conditions, the lowest activity of ATP sulfurylase was observed in young and old leaves of Naehan, with a decrease of $61.5 \%$ and $68.2 \%$ compared to the control, respectively.

\section{Relationship between ATP sulfurylase activity and $\mathrm{SO}_{4}{ }^{2-}$ uptake}

To estimate the relationship between ATP sulfurylase activity and $\mathrm{SO}_{4}{ }^{2-}$ uptake among different cultivars of rape under S-deficient conditions, scatter plots were used(Fig. 1). Under S-limited conditions $\left(0.2 \mathrm{mM} \quad \mathrm{SO}_{4}{ }^{2-}\right)$, ATPs activities were variable among cultivars,

Table 1. Changes in ATP sulfurylase activity in young and old leaves of ten cultivars

\begin{tabular}{lcccccc}
\hline \multirow{2}{*}{ Cultivar } & \multicolumn{2}{c}{ Young leaves $\left(\mathrm{U} \mathrm{g}^{-1} \mathrm{FW}\right)$} & & \multicolumn{2}{c}{ Old leaves $\left(\mathrm{U} \mathrm{g}^{-1} \mathrm{FW}\right)$} \\
\cline { 2 - 3 } \cline { 5 - 6 } & $2.0 \mathrm{mM} \mathrm{SO}_{4}{ }^{2-}$ & $0.2 \mathrm{mM} \mathrm{SO}_{4}{ }^{2-}$ & & $2.0 \mathrm{mM} \mathrm{SO}_{4}{ }^{2-}$ & $0.2 \mathrm{mM} \mathrm{SO}_{4}{ }^{2-}$ \\
\hline \hline Mosa & $101.2 \pm 3.2$ & $63.7 \pm 2.9$ & & $84.4 \pm 3.0$ & $32.6 \pm 5.1$ \\
Capitol & $96.0 \pm 7.6$ & $73.8 \pm 8.8$ & & $82.7 \pm 2.4$ & $28.9 \pm 4.0$ \\
Saturnin & $109.0 \pm 1.3$ & $58.7 \pm 2.0$ & & $84.5 \pm 6.2$ & $41.3 \pm 4.3$ \\
Akela & $109.5 \pm 5.0$ & $62.4 \pm 4.8$ & & $83.4 \pm 5.3$ & $37.0 \pm 2.7$ \\
Pollen & $92.6 \pm 9.9$ & $57.9 \pm 6.4$ & & $102.9 \pm 1.2$ & $33.4 \pm 3.8$ \\
Mokpo & $86.7 \pm 6.9$ & $63.4 \pm 7.4$ & & $77.9 \pm 1.0$ & $30.8 \pm 1.7$ \\
Youngsan & $93.3 \pm 2.3$ & $52.9 \pm 3.1$ & & $72.7 \pm 2.1$ & $42.3 \pm 1.9$ \\
Tamra & $81.9 \pm 10.2$ & $65.3 \pm 14.8$ & & $77.7 \pm 0.5$ & $40.0 \pm 6.1$ \\
Colosse & $94.8 \pm 12.0$ & $72.4 \pm 17.0$ & & $84.6 \pm 3.3$ & $35.4 \pm 3.6$ \\
Naehan & $123.5 \pm 1.8$ & $47.5 \pm 2.9$ & & $88.7 \pm 2.0$ & $28.2 \pm 0.9$ \\
\hline
\end{tabular}

The values are means \pm SD $(n=3)$. 

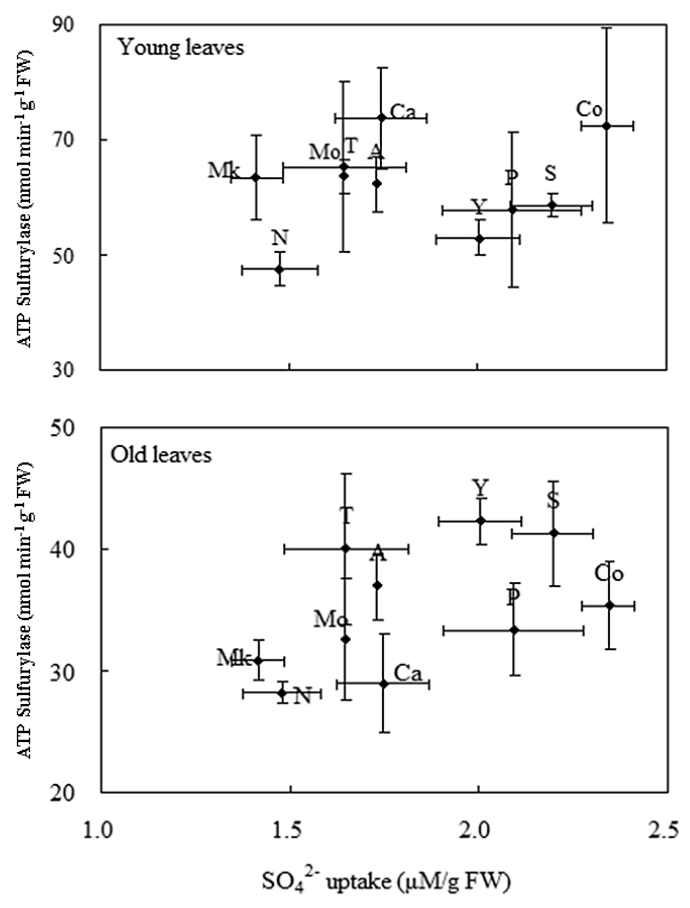

Fig. 1. Correlations exist between ATP sulfurylase and $\mathrm{SO}_{4}{ }^{2-}$ uptake either in young or in old leaves of rape plants under S-limited conditions. Mo, Mosa; Ca, Capital; S, Saturnin; A, Akela; P, Pollen; Mk, Mokpo; Y, Youngsan; T, Tamra; Co, Colosse; $\mathrm{N}$, Naehan. Leaf samples derived from 8-week-old pants which were exposed to S-deficient medium for 3 days before harvest. The values are means $\pm S D(n=3)$.

ranging from 47.5 to $73.8 \mathrm{U} \cdot \mathrm{g}^{-1} \mathrm{FW}$ in young leaves, and from 28.2 to $42.3 \mathrm{U} \cdot \mathrm{g}^{-1} \mathrm{FW}$ in old leaves. The results obtained clearly showed that the activity of ATP sulfurylase was various in different age of leaves. The comparison, within the same cultivar a higher ATPs activity was observed in young leaves than in old leaves. In young leaves, the lowest ATP sulfurylase was observed in Naehan. In old leaves, the relationship between two physiological parameters was well correlated, whereas the consistency was weaker in young leaves. Simultaneously, Saturnin and Youngsan having high $\mathrm{SO}_{4}{ }^{2-}$ uptake were at medium ATPs activity level in young leaves, but in old leaves the activities were higher than others.

\section{Glutathione concentration}

$\mathrm{S}$ deficiency resulted in a significant $(\mathrm{p}<0.05)$ increase in GSH concentration extracted from young leaves of all cultivars, representing a range from 247.6 (Mokpo) to $416.1 \mathrm{nmol}^{-1}$ (Mosa) (Fig. 2). And the highest rate of increase in GSH concentration was found in Akela

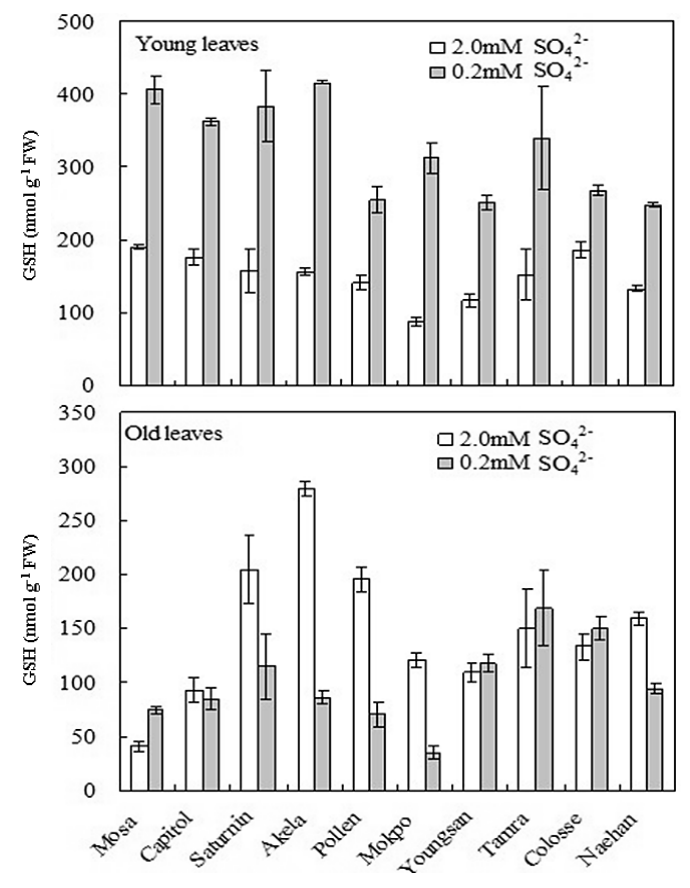

Fig. 2. Effects of different $\mathrm{SO}_{4}{ }^{2-}$ supply level on glutathione (GSH) concentration in young and old leaves. Leaf samples derived from 8-week-old pants which were exposed to Sdeficient medium for 3 days before harvest. The values are means \pm $\operatorname{SD}(n=3)$. 
(63\%), followed by Saturnin (59\%) and Mosa (53\%). In old leaves, GSH concentration was less affected by S-deficient treatment. However, a significant $(\mathrm{p}<0.05)$ decrease was observed in Akela (-79\%), Pollen $(-72 \%)$, Saturnin $(-70 \%)$.

\section{DISCUSSION}

ATP sulfurylase activity decreased in all ten cultivars after S-deficient application either in young or old leaves (Table 1). Previous study has been reported that ATP sulfurylase activity was reduced in response to $\mathrm{S}$ starvation (Logan et al., 1996). However, in roots the $S$ supply status has an adverse effect on ATPs activity, as demonstrated by Lappartient and Touraine (1996), they found that the activity of ATP sulfurylase extracted from roots of intact canola (Brassica napus L. cv Drakkar) increased after withdrawal of $\mathrm{S}$ source from the nutrient solution. Under limited S conditions, the activity of ATP sulfurylase was higher in young leaves than that of old leaves, which is consistent with previous findings (Adams and Rinne, 1969). Previous study (Abdallah et al., 2010) showed that in S-deficient rape plant $65 \%$ of S absorbed was found in roots; only approximate $23 \%$ was in leaves, which suggested that root might function as sulfur source when exogenous $\mathrm{S}$ was restricted. The results obtained showed a clear difference in the activity of ATP sulfurylase among various rape cultivars, which suggesting that rape cultivars differ in their capacity to utilize sulfate under limited $\mathrm{S}$ conditions. The relationship between two physiological parameters is well consistent with the response of ATP sulfurylase to $\mathrm{SO}_{4}{ }^{2-}$ uptake; it might be due to uptake and assimilation of sulfate regulated in response to sulfate demand which varies in different cultivars. Under S-deficient conditions, a higher ATPs activity was observed in young leaves than in old leaves, consistent with previous findings ( $\mathrm{Li}$ et al., 2009), indicating the active of sulfate assimilation located in young tissue rather than in old tissue.

It is well known that GSH is an antioxidant, and it is widely used as a marker of oxidative stress and as a storage and transport form of reduced sulfur (Tausz et al., 2004). In young leaves, $\mathrm{S}$ deficiency $\left(0.2 \mathrm{mM} \mathrm{SO}_{4}{ }^{2-}\right)$ significantly increased GSH concentration in all cultivars (Fig. 2) which is in agreement with the study of Hartmann et al. (2004) and Rennenberg (1984), they suggested that the accumulation of GSH was partly due to the exportation from matured leaves. However, Smith and Lang (1988) pointed out that over $90 \%$ of $\mathrm{S}$ transported out of the soybean mature leaves was recovered as $\mathrm{SO}_{4}{ }^{2-}$, and the export of GSH derived from mature leaves was negligible. Considering the young leaves are more susceptible to $\mathrm{S}$ deficiency, the increased GSH may contribute to defense against the negative effect from limited $\mathrm{S}$ nutrient.

Taken together, present study revealed that sulfate uptake and assimilation vary within different rape cultivars. The results may also give insight in the quality of cultivars, which can supply a strategy for further use in agricultural fields where the sulfur availability is limited.

\section{ABSTRACT}

To determine sulfate uptake and assimilation of various rape cultivars (Brassica napus L.) under different $\mathrm{S}$ levels, the activity of ATP sulfurylase, $\mathrm{SO}_{4}{ }^{2-}$ uptake and glutathione (GSH) 
concentrations were measured in different age of leaves. In this study, ten rape cultivars (Mokpo, Tamra, Youngsan, Naehan, Saturnin, Akela, Mosa, Capitol, Pollen, and Colosse) showed various sulfate uptake and assimilation capacity in response to inefficient sulfate supply. Under inadequate sulfate conditions, a greater ATP sulfurylase activity in young leaves was observed in all cultivars compared to that of old leaves. In addition, GSH concentration was considerably increased in young leaves when S supply was declined from 2.0 to $0.2 \mathrm{mM}$. These results suggested that rape cultivars differ in their capacity to utilize sulfate under limited $\mathrm{S}$ conditions.

\section{ACKNOWLEDGMENT}

This study was supported by Technology Development Program for Agriculture and Forestry, Ministry of Agriculture and Forestry, Republic of Korea.

\section{REFERENCES}

1. Abdallah, M., L. Dubousset, F. Meuriot, P. Etienne, J.C. Avice and A. Ourry. 2010. Effect of mineral sulphur availability on nitrogen and sulphur uptake and remobilization during the vegetative growth of Brassica napus L. J. Exp. Bot. 61:2635-2646.

2. Adams, C.A. and R.W. Rinne. 1969. Influence of age and sulphur metabolism on ATP sulfurylase activity in the soybean and a survey of selected species. Plant Physiol. 44:1241-1246.

3. Ahmad, A.I. Khan, N. A. Anjum, Y.P. Abrol and M. Iqbal. 2005. Role of sulphate transporter systems in sulphur efficiency of mustard genotypes. Plant Sci. 169:842-846.

4. Aulakh, M.S. 2003. Crop responses to sulphur nutrition. In: Y.P. Abrol, A. Ahmad (Eds.),
Sulphur in Plants, Kluwer Academic Publishers, Dordrecht, pp. 341-354.

5. Bell, C.I., D.T. Clarkson and W.J. Cram. 1995. Sulfate supply and its regulation of transport in roots of a tropical legume Macroptilium atropurpureum cv. Siratro. J. Exp. Bot. 46:65-71.

6. Blake-Kalff, M.M.A., K.R. Harrison, M.J. Hawkesford, F.J. Zhao and S.P. McGrath. 1998. Distribution of sulfur within oilseed rape leaves in response to sulfur deficiency during vegetative growth. Plant Physiol. 118:1337-1344.

7. Clarkson, D.T., F.W. Smith and P.J. van den Berg. 1983. Regulation of sulfate transport in a tropical legume, Macroptilium atropurpureum, cv. Siratro. J. Exp. Bot. 34:1463-1483.

8. Eriksen, J., K. Thorup-Kristensen and M. Askegard. 2004. Plant availability of catch crop sulfur following spring incorporation. J. Plant Nutr. Soil Sci. 167:609-615.

9. Hartmann, T., P. Hönicke, M. Wirtz, R. Hell, H. Rennenberg and S. Kopriva. 2004. Sulfate assimilation in poplars (Populus tremula $\times P$. alba) overexpressing $\mathrm{\gamma}$-glutamylcysteine synthetase in the cytosol. J. Exp. Bot. 55:837-845.

10. Herschbach, C. and H. Rennenberg. 1991. Influence of glutathione (GSH) on sulfate influx, xylem loading and exudation in excised tobacco roots. J. Exp. Bot. 42:1021-1029.

11. Herschbach C., E. van Der Zalm, A. Schneider, L. Jouanin, L.J. De Kok, and H. Rennenberg 2000. Regulation of sulfur nutrition in wild-type and transgenic poplar over-expressing $\mathrm{\gamma}$ glutamylcysteine synthetase in the cytosol as affected by atmospheric $\mathrm{H}_{2} \mathrm{~S}$. Plant Physiol. 124: 461-473.

12. Holmes, M.R.J. 1980. Nutrition of the Oilseed Rape Crop. Applied Science Publishers, London.

13. Kim, T.H., A. Ourry, J. Boucaud and G. Lemaire. 1991. Changes in source-sink relationship for nitrogen during regrowth of lucerne(Medicago sativa L.) following removal of shoots. Aust. J. Plant Physiol. 18:593-602.

14. Lappartient, A.G. and B. Touraine. 1996. Demanddriven control of root ATP Sulfurylase activity and $\mathrm{SO}_{4}{ }^{2-}$ uptake in Intact Canola. Plant Physiol. 111:147-157. 
15. Lappartient, A.G., J.J. Vidmar, T. Leustek, A.D.M. Glass and B. Touraine. 1999. Inter-organ signaling in plants: regulation of ATP sulfurylase and sulfate transporter genes expression in roots mediated by phloem-translocated compound. Plant J. 18:89-95.

16. Legge, A.H. and S.V. Krupa. 2002. Effects of sulphur dioxide, in: Bell J.N.B., M. Treshow (Eds.), Air pollution and plant life, John Wiley \& Sons, Chichester, pp. 135-162.

17. Leustek, T. 2002. Sulfate metabolism. In CR Somerville, EM Meyerowitz, eds, The Arabidopsis Book. American Society of Plant Biologists, Rockville, MD, doi/10.1199/tab.0009.

18. Li, L.S., Y.L. Jin, B.R. Lee and T.H. Kim. 2009. Sulfur deficiency effects on sulfate uptake and assimilatory enzymes activity in rate plants. J. Kor. Grass. Forage Sci. 29(2):95-102.

19. Logan, H.M., N. Cathala, C. Grignon and J.C. Davidian. 1996. Cloning of a cDNA encoded by a member of the Arabidopsis thaliana ATP sulfurylase multigene family: expression studies in yeast and in relation to plant sulfur nutrition. J. Biol. Chem. 271:12227-12233.

20. Noctor, G., L. Gomez, H. Vanacker and C.H. Foyer. 2002. Interactions between biosynthesis, compartmentation and transport in the control of glutathione homeostasis and signaling. J. Exp. Bot. 53:1283-1304.

21. Rennenberg, H. 1984. The fate of excess sulfur in higher plants. Annu. Rev. Plant Physiol. 35:121135.

22. Ruiz, J.M. and E. Blumwald. 2002. Salinityinduced glutathione synthesis in Brassica napus. Planta. 214, 965-969.

23. Saito, K. 2004. Sulfur assimilatory metabolism: the long and smelling road. Plant Physiol. 136: 2443-2450.

24. Scherer, H.W. 2001. Sulphur in crop production. Eur. J. Agron. 14:81-111.

25. Smith, I.K. and A.L. Lang. 1988. Translocation of sulfate in soybean (Glycine $\max$ L. Merr). Plant Physiol. 86:798-802.

26. Tausz, M., J.H. Šircel and D. Grill. 2004. The glutathione system as stress marker in plant ecophysiology: is a stress-response concept valid? J. Exp. Bot. 55:1955-1962.

27. Zhao, F.J., P.J.A. Whiters, E.J. Evans, J. Monaghan, S.E. Salomon, P.R. Shewry and S.P. McGrath. 1997. Sulphur nutrition: An important factor for the quality of wheat and rapeseed. Soil. Sci. Plant Nutr. 43:1137-1114.

(Received February 15, 2012/Accepted June 12, 2012) 